\title{
Effect of carboxymethylcellulose on the rheological and filtration properties of bentonite clay samples determined by experimental planning and statistical analysis
}

\author{
(Efeito da carboximetilcelulose nas propriedades reológicas \\ e de filtração de argilas bentoníticas determinadas por planejamento \\ experimental e análise estatística)
}

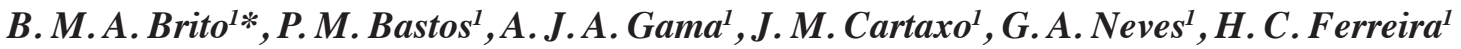 \\ ${ }^{1}$ Universidade Federal de Campina Grande, Centro de Ciências e Tecnologia, Unidade Acadêmica de \\ Engenharia de Materiais, R. Aprígio Veloso 882, 58429-900, Campina Grande, PB, Brazil
}

\begin{abstract}
Over the past few years, considerable research has been conducted using the techniques of mixture delineation and statistical modeling. Through this methodology, applications in various technological fields have been found/optimized, especially in clay technology, leading to greater efficiency and reliability. This work studied the influence of carboxymethylcellulose on the rheological and filtration properties of bentonite dispersions to be applied in water-based drilling fluids using experimental planning and statistical analysis for clay mixtures. The dispersions were prepared according to Petrobras standard EP-1EP-00011-A, which deals with the testing of water-based drilling fluid viscosifiers for oil prospecting. The clay mixtures were transformed into sodic compounds, and carboxymethylcellulose additives of high and low molar mass were added, in order to improve their rheology and filtrate volume. Experimental planning and statistical analysis were used to verify the effect. The regression models were calculated for the relation between the compositions and the following rheological properties: apparent viscosity, plastic viscosity, and filtrate volume. The significance and validity of the models were confirmed. The results showed that the 3D response surfaces of the compositions with high molecular weight carboxymethylcellulose added were the ones that most contributed to the rise in apparent viscosity and plastic viscosity, and that those with low molecular weight were the ones that most helped in the reduction of the filtrate volume. Another important observation is that the experimental planning and statistical analysis can be used as an important auxiliary tool to optimize the rheological properties and filtrate volume of bentonite clay dispersions for use in drilling fluids when carboxymethylcellulose is added.
\end{abstract} Keywords: drilling fluids, bentonite, carboxymethylcellulose, rheological properties, experimental planning.

\section{Resumo}

Pesquisas utilizando delineamento de misturas e modelos estatísticos têm sido realizadas nos últimos anos. Por meio desta metodologia foram otimizadas/descobertas aplicações em várias áreas tecnológicas, principalmete em tecnologia de argilas. A influência da carboximetilcelulose sobre as propriedades reológicas e de filtração das dispersões de bentonita para aplicação em fluidos de perfuração base água, utilizando a técnica de planejamento experimental e análise estatística para misturas de argilas, foi estudada neste trabalho. As dispersões foram preparadas de acordo com a norma da Petrobras EP-1EP-00011-A que trata do ensaio de viscosificantes para fluidos de perfuração base água para prospecção de petróleo. As misturas de argilas foram transformadas em sódicas e posteriormente aditivadas com carboximetilcelulose de massa molar alta e baixa, com a finalidade de melhorar sua reologia e volume de filtrado. Foi utilizado o planejamento experimental e análise estatística para verificar seu efeito. Os modelos de regressão foram efetuados, fazendo uma relação entre as composições e as propriedades reológicas: viscosidade aparente, viscosidade plástica $e$ volume de filtração. A significância e a validade dos modelos foram confirmadas. Os resultados mostraram que as superfícies de respostas $3 D$ das composições aditivadas com carboximetilcelulose de alta massa molecular foram as que mais contribuíram para aumentar a viscosidade aparente e viscosidade plástica, e que as de baixa massa molecular foram que as mais auxiliaram na redução do volume de filtrado. Outra observação relevante é que o planejamento experimental com análise estatística pode ser utilizado como ferramenta auxiliar importante para otimizar as propriedades reológicas e volume de filtrado de dispersões de argilas bentoníticas para uso em fluídos de perfuração quando aditivadas com carboximetilcelulose.

Palavras-chave: fluidos de perfuração, bentonita, carboximetilcelulose, propriedades reológicas, planejamento experimental.

\section{INTRODUCTION}

Bentonite is a sedimentary clay formed by devitrification and posterior chemical alteration of volcanic ash or tuff, essentially composed of montmorillonite, a clay mineral of the smectite group. This type of clay is made of lamella and formed by an octahedral sheet of alumina $\left(\mathrm{Al}_{2} \mathrm{O}_{3}\right)$ between two tetrahedral sheets of silica $\left(\mathrm{SiO}_{2}\right)$ [1-3]. 
Specific characteristics such as large surface areas, cation exchange, and hydration capacity make bentonite suitable for a variety of industrial applications [4]. Bentonite is used as an industrial raw material in more than 40 applications [5, 6], such as adsorption agents, manufacturing of high value products with nanomaterials, medicine and fine chemicals [7]. It is also used as a raw material in the cosmetics industry [8]. Moreover, due to its high adsorption capacity and chemical stability, bentonite is widely used in the processed food industry [9]. An important application of bentonite dispersions is their use as drilling fluid in the petroleum industry, since they are capable of forming viscoelastic and thixotropic dispersions. These drilling fluids are of great importance, as they must cool down the drill, remove gravel created at the perforation, and keep the well stable. In the form of gel, they must be able to stop gravel when drilling pauses for some intermediate activity, and turn into gel again when drilling restarts $[1,10,11]$.

Bentonite found in Brazilian deposits is usually polycationic. In order to be used in an industrial application, such as drilling fluid, they must be turned sodic and have a high swelling capacity. In this process, clay is treated with $\mathrm{Na}_{2} \mathrm{CO}_{3}$, causing a double exchange reaction in which the $\mathrm{Ca}^{2+}$ cations of the clay combine with $\left(\mathrm{CO}_{3}\right)^{2-}$ coming from the sodium carbonate in an aqueous solution, becoming calcium carbonate. At the same time, $\mathrm{Na}^{+}$cations bond in the exchange positions in the inter-layers of the clay minerals, making it sodic. The reduced particle size, high charge, and large surface area of sodic bentonite cause high thixotropy in aqueous dispersions. This, together with its high swelling capacity, makes sodic bentonite a key component of water-based drilling fluids $[4,12]$. When it does not present the appropriate rheological and filtration properties, it becomes necessary to use secondary additives such as: calcium chloride $\left(\mathrm{CaCl}_{2} \cdot 2 \mathrm{H}_{2} \mathrm{O}\right)$, magnesium oxide $(\mathrm{MgO})$, and carboxymethylcellulose - $\mathrm{CMC}$ $\left[\mathrm{C}_{6} \mathrm{H}_{7} \mathrm{O}_{2}(\mathrm{OH})_{x}\left(\mathrm{OCH}_{2} \mathrm{COONa}\right)_{y}\right]$ [13]. CMC additive normally acts by raising viscosity and reducing the filtrate. This characteristic makes it capable of absorbing large amounts of water and being used to control the loss of filtrate in many types of fluid systems [1]. The high molecular weight CMC increases the thickness of the filtrate as well as the viscosity in fluids containing clay. This is due to the physical interactions formed by weak bonds (repelling forces) between the carboxylate anions present in the CMC molecule and the charges present in the clay, favored by the hydration of the polymer chain and the clay in aqueous media. The use of low molecular weight CMC also reduces the losses caused by filtration and produces very thin layers, which are capable of blocking the flow of fluid through the permeable geological formations that are being perforated [14].

Some research studies that employ mixture delineation and statistical modeling have been published, with some important highlights in [15-18]. This methodology has found important applications in several technological fields, having been applied in the field of clay technology with great success $[15,17,19-23]$. In all cases, it has led to greater efficiency and more reliable results, while simultaneously allowing systems to be optimized with a minimal number of experiments. On the other hand, there are few reports making use of experimental planning in order to achieve the desired rheological and filtration properties and establish an optimized composition with a reduced number of tests on the interaction between polymers and clay samples coming from different areas of the deposit located in Olivedos-PB, Brazil.

Strengthening the research on the interaction of clay minerals with polymers and the influence of additives on the rheological properties of clay dispersions is very important to the field of drilling fluids for the petroleum industry, as these dispersions must conform to the Petrobras standards [24]. The improvement of bentonite using CMC raises the viscosity, reducing the loss of drilling fluid and maintaining proper flow properties under conditions of moderate temperature, salinity and pressure, providing improvements in the required technological properties. From this perspective, the purpose of this study is the investigation of the influence of CMC on the rheological and filtration properties of bentonite dispersions to be applied in water-based drilling fluids, using experimental planning and statistical analysis on mixtures of clay samples coming from the town from Olivedos, Paraíba, Brazil.

\section{MATERIALS AND METHODOLOGY}

To carry out this study, bentonite clay samples were used, called M1 and M2, taken from new deposits in the municipality of Olivedos in the State of Paraíba, in the northeastern region of Brazil. The samples were dried in an oven at a temperature of about $60{ }^{\circ} \mathrm{C}$, and then ground in a ball mill with diameter under $75 \mu \mathrm{m}$. These samples were obtained by mixing clay (blends) from different areas of the deposit, using the experimental modeling technique known as mixture delineation [15]. The additives used were: anhydrous sodium carbonate $\mathrm{PA}\left(\mathrm{Na}_{2} \mathrm{CO}_{3}\right)$, manufactured by

Table I - Chemical composition and cation exchange capacity of the blends under study.

[Tabela I - Composição química e capacidade de troca de cátions dos blends estudados.]

\begin{tabular}{cccccccccc}
\hline Sample & $\begin{array}{c}\mathrm{SiO}_{2} \\
(\%)\end{array}$ & $\begin{array}{c}\mathrm{Al}_{2} \mathrm{O}_{3} \\
(\%)\end{array}$ & $\begin{array}{c}\mathrm{MgO} \\
(\%)\end{array}$ & $\begin{array}{c}\mathrm{Fe}_{2} \mathrm{O}_{3} \\
(\%)\end{array}$ & $\begin{array}{c}\mathrm{CaO} \\
(\%)\end{array}$ & $\begin{array}{c}\mathrm{TiO}_{2} \\
(\%)\end{array}$ & $\begin{array}{c}\text { Other } \\
\text { oxides }(\%)\end{array}$ & $\begin{array}{c}\text { LI (\%) } \\
\text { CEC (meq/100g } \\
\text { dry clay) }\end{array}$ \\
\hline $\mathrm{M} 1$ & 51.1 & 22.3 & 3.3 & 4.6 & 3.8 & 0.6 & 0.9 & 13.4 & 68 \\
$\mathrm{M} 2$ & 50.7 & 21.7 & 3.4 & 4.6 & 3.8 & 0.6 & 1.0 & 14.0 & 72 \\
\hline
\end{tabular}

Notes: LI - loss on ignition; CEC - cation exchange capacity. 
Vetec; high molecular weight (HW) carboxymethylcellulose (CMC, $2.5 \times 10^{-5} \mathrm{~g} / \mathrm{mol}$ ), and low molecular weight (LW) carboxymethylcellulose $\left(9.0 \times 10^{-4} \mathrm{~g} / \mathrm{mol}\right)$. The physical, chemical and mineralogical characterization of the samples were performed in [15]. In Table I, the values of the chemical analysis by X-ray fluorescence (EDX), using a Shimadzu 720 device, and the cation exchange capacity (CEC), using the methylene blue method [25], are present.

The bentonites were mixed in different compositions and $\mathrm{Na}_{2} \mathrm{CO}_{3}$ was added at a ratio of $125 \mathrm{meq} / 100 \mathrm{~g}$ of dry clay, and cured for a period of five days to allow the cation exchange to occur. To prepare the dispersions, $24.3 \mathrm{~g}$ of clay ( $4.86 \%$ by mass) was used with $500 \mathrm{~mL}$ of deionized water, according to Petrobras' standard [24], then homogenized by a Marconi $500 \mathrm{~W}$ agitator at approximately $15000 \mathrm{rpm}$ for 20 $\mathrm{min}$, and then rested for $24 \mathrm{~h}$. After standing, the dispersions were agitated again and their rheological properties were measured. The rheological parameters, apparent viscosity $(\mathrm{AV})$, and plastic viscosity (PV), were measured by means of a Fann 35A viscosimeter, according to Petrobras' standard [24], using Eqs. A and B:

$$
\mathrm{AV}=300 \frac{\theta}{\mathrm{N}}
$$

where $\mathrm{AV}$ is the apparent viscosity given in $\mathrm{mPa} . \mathrm{s}, \mathrm{N}$ is the rotational speed of the Fann viscometer at $600 \mathrm{rpm}$, and $\theta$ is the deflection measured in the viscometer at this speed;

$$
\mathrm{PV}=300 \frac{\theta_{2}-\theta_{1}}{\mathrm{~N}_{2}-\mathrm{N}_{1}}
$$

where, $\mathrm{PV}$ is the plastic viscosity given in mPa.s, $\theta_{2}$ and $\mathrm{N}_{2}$

Table II - Proportions of the composition components (wt\%), obtained by means of the simplex-lattice centroid network $\{3.2\}$ augmented with interior points, for the blends having LW and HW CMC additives.

[Tabela II - Proporções dos componentes (\% em massa) de composições obtidas através do planejamento em rede simplex-lattice centroide $\{3,2\}$ aumentado com pontos interiores, para os blends aditivados com CMC LW e HW.]

\begin{tabular}{cccc}
\hline Composition & M & LW CMC & HW CMC \\
\hline 1 & 100.00 & 0.00 & 0.00 \\
2 & 98.00 & 2.00 & 0.00 \\
3 & 98.00 & 0.00 & 2.00 \\
4 & 99.00 & 1.00 & 0.00 \\
5 & 99.00 & 0.00 & 1.00 \\
6 & 98.00 & 1.00 & 1.00 \\
7 & 99.34 & 0.33 & 0.33 \\
8 & 98.34 & 1.33 & 0.33 \\
9 & 98.34 & 0.33 & 1.33 \\
10 & 98.66 & 0.67 & 0.67 \\
\hline
\end{tabular}

Notes: $M$ - clay; $L W C M C$ - low molecular weight carboxymethylcellulose; $H W C M C$ - high molecular weight carboxymethylcellulose. are measured at $600 \mathrm{rpm}$, and $\theta_{1}$ and $\mathrm{N}_{1}$ are measured at $300 \mathrm{rpm}$. The filtrate volume (FV) was determined using a filter press test, in which the dispersion was inserted and the filtrate collected over a period of $30 \mathrm{~min}$ after the application of $690 \pm 35 \mathrm{kPa}(100 \pm 5 \mathrm{psi})$ of pressure.

After being transformed into sodic compounds, both high and low viscosity CMC were added to the blends, using the experimental modeling by mixture delineation [26]. In order to define the compositions, simplex-lattice network planning $\{4.2\}$ was used, for a total of fifteen experimental runs, and to perform the analyses of the rheological and filtration properties, simplex centroid network $\{3.2\}$ planning was used, augmented with interior points, for a total of ten experimental runs, as shown in Table II. These experiments were executed randomly, with one replica for each planning type. To perform the statistical analysis, the following parameters were taken into account: the $\mathrm{F}$ test, the ratio between the computed $\mathrm{F}$ and the tabulated $\mathrm{F}$, the $\mathrm{p}$-value, and the correlation coefficient $\mathrm{R}^{2}$. These parameters were computed by means of variance analysis (ANOVA), using the Statistica 7 software.

\section{RESULTS AND DISCUSSION}

In Table III, the rheological parameters of the dispersions prepared from the M1 sample with both low (LW) and high (HW) molecular weight CMC additives are listed, established by the simplex centroid network $\{3.2\}$ planning, augmented with interior points. These values demonstrate that the parameters of the sample M1 under study were enhanced when added with CMC, both LW and HW. Some compositions had their PV rise from 1 to $13 \mathrm{mPa}$.s while FV decreased from 30 to $16 \mathrm{~mL}$. The increase in the apparent viscosity was less prominent than the other two parameters, $\mathrm{PV}$ and $\mathrm{FV}$.

In Table IV, the values of the principal statistical parameters for the linear, quadratic, special cubic, and full cubic models are presented, obtained from the $\mathrm{AV}$, $\mathrm{PV}$ and FV experimental data, relative to the M1 clay compositions with LW and HW CMC additives. Table V contains the values of the principal statistical parameters for no adjustment relative to the same models, obtained from these experimental data. The values presented in Tables IV and V (p-value, correlation coefficient $\mathrm{R}^{2}, \mathrm{~F}$ test, and relation $\mathrm{F}_{\text {cal }} / \mathrm{F}_{\text {tab }}$ ) demonstrate that, for the parameter $\mathrm{AV}$, the $\mathrm{R}^{2}$ value of the linear statistical model is less than that of the full cubic model. Nevertheless, the linear model was chosen over the full cubic model, because the $\mathrm{F}_{\text {cal }}$ value and the relation $\mathrm{F}_{\text {cal }} / \mathrm{F}_{\text {tab }}$ were higher. It was also concluded that, for parameters PV and FV, the most suitable statistical model was the full cubic. These models were therefore selected for creating the correlation equations, the 3D response surfaces, the level curves, the response trace plots, and the statistical parameters. The $\mathrm{R}^{2}$ values in Table IV, for the most suitable model chosen for parameters AV, PV and $\mathrm{FV}$, respectively, of $0.800,0.956$ and 0.950 , indicated that the models were well-adjusted. The p-value showed that the 
Table III - Rheological and filtration parameters of compositions of sample M1 with LW and HW CMC additives.

[Tabela III - Parâmetros reológicos e de filtração de composições da amostra MI aditivada com CMC LW e HW.]

\begin{tabular}{ccccccc}
\hline \multirow{2}{*}{ Composition } & AV (mPa.s) & Test & Repetition & \\
& 19.75 & 1.00 & 30.00 & 17.00 & 2.00 & 30.00 \\
2 & 15.00 & 10.00 & 17.00 & 16.00 & 10.00 & 17.00 \\
3 & 21.50 & 13.00 & 17.00 & 23.50 & 11.00 & 17.00 \\
4 & 15.40 & 8.80 & 20.00 & 15.40 & 8.80 & 18.00 \\
5 & 20.00 & 12.00 & 21.00 & 20.00 & 11.00 & 23.00 \\
6 & 18.00 & 10.00 & 16.00 & 18.50 & 10.00 & 16.00 \\
7 & 17.00 & 9.00 & 18.00 & 17.50 & 10.00 & 16.00 \\
8 & 15.00 & 8.00 & 24.00 & 14.50 & 9.00 & 21.00 \\
9 & 22.00 & 13.00 & 17.00 & 18.50 & 11.00 & 20.00 \\
10 & 18.50 & 9.00 & 17.00 & 19.50 & 10.00 & 18.00 \\
\hline \multicolumn{7}{r}{ Standard EP-1EP-00011-A (Petrobras, 2011$): \mathrm{AV} \geq 15 \mathrm{mPa} .5 ;$ PV $\geq 4 \mathrm{mPa} . \mathrm{s} ; \mathrm{FV} \leq 18 \mathrm{~mL}$} \\
\hline \multicolumn{7}{c}{}
\end{tabular}

Table IV - Statistical parameters of the variance analyses of the variables $\mathrm{AV}, \mathrm{PV}$ and $\mathrm{FV}$ relative to the model, of compositions of the M1 sample with LW and HW CMC additives.

[Tabela IV - Parâmetros estatísticos das análises de variância das variáveis $V A, V P$ e $V F$, relativos ao modelo, de composições da amostra M1 aditivada com CMC LW e $H W$.

\begin{tabular}{cccccc}
\hline Variable & Model & $\mathrm{F}_{\text {cal }}$ test & $\mathrm{F}_{\text {cal }} / \mathrm{F}_{\text {tab }}$ & $\mathrm{p}$-value & $\mathrm{R}^{2}$ \\
\hline AV & Linear & $\mathbf{3 3 . 9 2 6}$ & $\mathbf{9 . 4 5 0}$ & $\mathbf{0 . 0 0 0 0 0}$ & $\mathbf{0 . 8 0 0}$ \\
AV & Quadratic & 13.841 & 4.676 & 0.00005 & 0.832 \\
AV & Special cubic & 11.196 & 3.834 & 0.00017 & 0.838 \\
AV & Full cubic & 8.152 & 2.763 & 0.00111 & 0.856 \\
PV & Linear & 12.751 & 3.552 & 0.00041 & 0.600 \\
PV & Quadratic & 23.114 & 7.809 & 0.00001 & 0.892 \\
PV & Special cubic & 14.659 & 5.020 & 0.00001 & 0.901 \\
PV & Full cubic & $\mathbf{2 9 . 6 0 3}$ & $\mathbf{1 0 . 0 3 5}$ & $\mathbf{0 . 0 0 0 0 0}$ & $\mathbf{0 . 9 5 6}$ \\
FV & Linear & 7.828 & 2.180 & 0.00389 & 0.479 \\
FV & Quadratic & 4.297 & 1.452 & 0.01407 & 0.605 \\
FV & Special cubic & 3.329 & 1.140 & 0.03274 & 0.606 \\
FV & Full cubic & $\mathbf{2 6 . 1 0 0}$ & $\mathbf{8 . 8 4 8}$ & $\mathbf{0 . 0 0 0 0 0}$ & $\mathbf{0 . 9 5 0}$
\end{tabular}

Notes: $F_{c a l}$ - computed $F$ test (Fisher's test); $F_{c a} / F_{t a b}$ - relation between the computed $F$ test and the tabulated F test; $p$-value - probability level of significance; $R^{2}$ - correlation coefficient.

models were statistically significant at the stipulated level ( $p$-value $\geq$ significance level) for the rheological parameters $\mathrm{AV}$ and PV, as well as for the filtration parameter FV. The ratio between the computed and tabulated F-values proved that the models were significant for all parameters, and were predictive for $\mathrm{PV}$ and FV, considering that, in this case, the tabulated F-value was five times higher than the computed value. The analysis of the $\mathrm{p}$-value in Table $\mathrm{V}$ indicated that, for the parameters $\mathrm{AV}, \mathrm{PV}$ and FV, the "no adjustment" condition was not statistically significant at the stipulated confidence level ( $p$-value $\geq$ significance level), meaning that, for those samples, there was no significant variability between the parameter values obtained in tests and in their replicas. The values for the $\mathrm{F}_{\text {cal }}$ test and the $\mathrm{F}_{\text {cal }} / \mathrm{F}_{\text {tab }}$ ratio also revealed that the model was not statistically significant for these parameters, with no adjustment.

Based on the results achieved with replicas, regression equations were generated, correlating proportions of the clay samples and the additives LW and HW CMC, by mass, with the parameters AV, PV and FV. These mathematical models are presented in Table VI. The terms of the AV equation indicate that the sample blend $\mathrm{M}^{*}$ and the $\mathrm{LW}^{*} / \mathrm{HW} * \mathrm{CMC}$ were all statistically significant, and all of them interacted synergistically. From the coefficients, it can be concluded that the HW CMC was the component that most contributed to the increase in this parameter. Since LW CMC is a shortchain polymer, its principal function is to reduce the filtration rate. Because HW CMC has a longer chain, it probably leads to the suspensions having a higher state of flocculation, thereby increasing the AV. From the terms of the PV equation, it can be seen that the blend sample $\mathrm{M}^{*}$ and the $\mathrm{LW}^{*} / \mathrm{HW}^{*}$ CMC, as well as the compositions MLW*, MHW* and MLW(M-LW)*, are statistically significant. The coefficients of the equation indicated that the components interacted synergistically, but that the HW CMC was the component that most contributed individually to increasing the plastic viscosity. On the other hand, the composition MLW(M-LW) had the highest coefficient, meaning that it increased this parameter more effectively. CMC contains a carboxymethyl 
Table V - Statistical parameters of the variance analysis relative to no adjustment, of the variables $\mathrm{AV}, \mathrm{PV}$ and $\mathrm{FV}$ for compositions of blend M1, with LW and $\mathrm{HW}$ CMC additives. [Tabela V - Parâmetros estatísticos das análises de variância das variáveis VA, VP e VF, relativos à falta de ajuste, de composições do blend M1, aditivada com CMC LW e HW.]

\begin{tabular}{ccccc}
\hline Variable & Model & $\mathrm{F}_{\text {cal }}$ test for “no adjustment" & $\mathrm{F}_{\text {cal }} / \mathrm{F}_{\text {tab }}$ & p-Value \\
\hline AV & Linear & 1.206 & 0.384 & 0.38061 \\
AV & Quadratic & 1.372 & 0.394 & 0.31692 \\
AV & Special cubic & 1.642 & 0.443 & 0.24156 \\
AV & Full cubic & 3.286 & 0.662 & 0.09997 \\
PV & Linear & 13.595 & 4.330 & 0.00022 \\
PV & Quadratic & 4.602 & 1.323 & 0.02291 \\
PV & Special cubic & 5.367 & 1.447 & 0.01842 \\
PV & Full cubic & 1.670 & 0.338 & 0.23531 \\
FV & Linear & 14.815 & 4.718 & 0.00015 \\
FV & Quadratic & 19.045 & 5.473 & 0.00011 \\
FV & Special cubic & 25.372 & 6.839 & 0.00005 \\
FV & Full cubic & 0.931 & 0.188 & 0.35742 \\
\hline
\end{tabular}

See footnotes in Table IV.

group $\left(-\mathrm{CH}_{2} \mathrm{OCH}_{2} \mathrm{COONa}\right)$ that liberates, in an aqueous solution, the $\mathrm{Na}^{+}$ion, becoming therefore anionic and hydratable. During hydration, the adsorbed molecules give the polymer an elongated configuration, increasing the viscosity of the system [27]. This phenomenon is more noticeable with the presence of bentonite in the suspension. In this case, the polymer interacts with the clay due to the formation of a solvation layer between the negative charges of the polymer and the positive charges present along the edges of the clay particles. Analysis of the terms of the FV equation allows the conclusion to be reached that the blend sample $\mathrm{M}^{*}, \mathrm{LW}^{*} / \mathrm{HW}^{*} \mathrm{CMC}$, as well as the compositions MLW* and MLW(M-LW)* were statistically significant. The coefficients also indicated that $\mathrm{M}^{*}, \mathrm{LW}^{*}$ and $\mathrm{HW}^{*}$ interacted synergistically and the compositions MLW* and MLW(M-LW)* interacted antagonistically, that is, the LW CMC was the component that acted positively in reducing the filtrate volume. LW $\mathrm{CMC}$, being a short-chain polymer, reduces the filtration rate. Short-chain polymers usually act as deflocculants, because they promote the neutralization of some of the clay particles' positive charges, one by one, covering them along the edges and increasing the distance between them [28]. According to [29] the reduction of FV occurs because the use of CMC in water-based fluids forms a lowpermeability film. The clay particles adsorb the polymer and help give consistency to the shell formed, making it less permeable.

Figs. $1 \mathrm{a}, 1 \mathrm{~b}$ and $1 \mathrm{c}$ illustrate the $3 \mathrm{D}$ response surfaces, relative to the $\mathrm{AV}, \mathrm{PV}$ and $\mathrm{FV}$, respectively, for the $\mathrm{M} 1$ sample with LW and HW CMC additives. The results indicated that the HW CMC additive is the component that most influenced the increase in both the AV and PV. The
LW CMC additive, for amount close to $2 \%$, contributed to a reduction in $\mathrm{AV}$ and, in smaller amounts, favored an increase in PV and reduction in FV. These tendencies can be more easily observed by means of the response trace plots. In Fig. 2, the superposition of the contours relative to the parameters $\mathrm{AV}, \mathrm{PV}$ and $\mathrm{FV}$, for the sample $(100 \%$ M1) with LW and HW CMC additives, is represented. In the region where the three parameters intersect (hatched area), compositions whose rheological parameters $\mathrm{AV}$ and $\mathrm{PV}$, and the filtration parameter $\mathrm{FV}$ meet the requirements established by Petrobras [24] for use in water-based drilling fluids can be found. In order to validate the model, values were assigned to each of the composition components within the area where the rheological and filtration parameters met the minimum requirements of Petrobras' standard [24]. Using the corresponding mathematical equations, the predicted values for each of these parameters was computed and then the methodology described before was applied to experimentally determine the values of these parameters, which are represented in Table VII. These values indicated that the parameters AV, $\mathrm{PV}$ and $\mathrm{FV}$, calculated by the mathematical equations and measured in laboratory tests, were very close, suggesting that the models were experimentally validated. In Fig. 3 , the graphs are plotted as a transverse cut along the response surfaces or trace response plots, which is an alternative manner of visualizing the effects of the change in proportion of the compositions on the rheological and filtration properties. The composition used to plot these graphs was composition 2 (Table VII), as this was the one whose predicted and experimentally measured values were closer, and also because its rheological and filtration parameters $(\mathrm{AV}, \mathrm{PV}$ and $\mathrm{FV})$ meet the requirements 
Table VI - Correlation equations of compositions of the M1 blend with LW and HW CMC additives. [Tabela VI - Equações matemáticas de correlação de composições do blend M1 aditivada com CMC LW e HW.]

\begin{tabular}{cl}
\hline Parameter & \multicolumn{1}{c}{ Equation } \\
\hline $\mathrm{AV}$ & $\mathrm{AV}=17.67 \mathrm{M}^{*}+14.34 \mathrm{LW}^{*}+22.37 \mathrm{HW}^{*}$ \\
$\mathrm{PV}$ & $\mathrm{PV}=1.55 \mathrm{M}^{*}+10.05 \mathrm{LW}^{*}+12.05 \mathrm{HW}^{*}+12.42 \mathrm{MLW}^{*}+19.23 \mathrm{MHW}^{*}+31.54 \mathrm{MLW}(\mathrm{M}-\mathrm{LW})^{*}$ \\
$\mathrm{FV}$ & $\mathrm{FV}=30.06 \mathrm{M}^{*}+17.06 \mathrm{LW}^{*}+17.06 \mathrm{HW}^{*}-17.75 \mathrm{MLW}^{*}-100.70 \mathrm{MLW}(\mathrm{M}-\mathrm{LW})^{*}$
\end{tabular}

Notes: $M$ - sample blend from Olivedos (100\% MI); LW and HW, respectively, low and high molecular weight CMC; the terms with an asterisk are statistically significant at the $95.0 \%$ confidence level.

established by Petrobras [24] for use in water-based drilling fluids. The analysis of Fig. 3 led to the conclusion that the increase in the amount of HW CMC had a positive influence on the rheological parameters, increasing both the apparent viscosity and the plastic viscosity, while having a negative influence on the filtration parameter, increasing the filtrate volume. Increasing the amount of LW CMC reduced the apparent viscosity and, in amounts below $0.6 \%$ and above $1.6 \%$, raised the plastic viscosity and reduced the filtrate volume.

In Table VIII, the rheological and filtration parameters of the dispersions prepared with sample M2 with LW and HW CMC additives are indicated, determined by simplex centroid network $\{3.2\}$ planning augmented with interior points. These values show that the rheological and filtration parameters of the M2 sample were affected similarly to those of the M1 sample, when LW and HW CMC were added, that is, the use of additives increased the AV and PV and reduced the FV. In Table IX the values of the principal statistical parameters for the linear, quadratic, special cubic, and full cubic models are presented, obtained from experimental data of $\mathrm{AV}, \mathrm{PV}$ and $\mathrm{FV}$, with respect to the compositions of the M2 sample with LW and HW CMC additives. Table X contains the values of the principal statistical parameters for no adjustment, for the same models, obtained from these experimental data. The values presented in Tables IX and $\mathrm{X}$, namely the $\mathrm{p}$-value, the correlation coefficient $\mathrm{R}^{2}$, the $\mathrm{F}$ test and the $\mathrm{F}_{\mathrm{cal}} / \mathrm{F}_{\text {tab }}$ ratio, showed that the statistical model that best fits the parameters $\mathrm{AV}, \mathrm{PV}$ and $\mathrm{FV}$ is

a)

b)
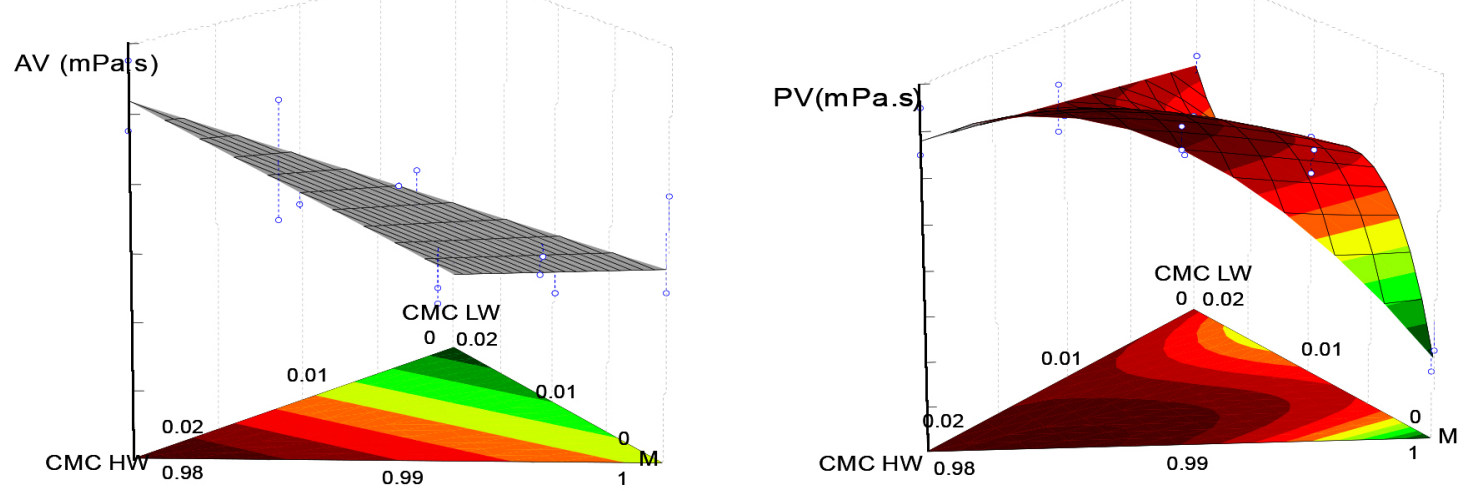

c)

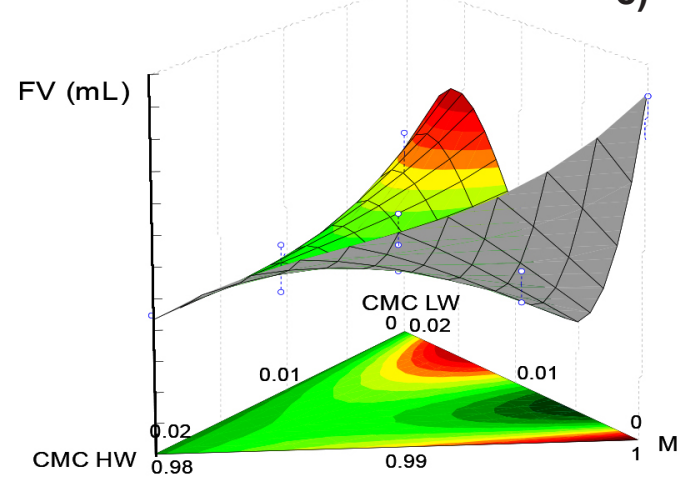

Figure 1: Projection of the 3D response surface of: (a) AV, calculated using the linear model; (b) PV, calculated using the full cubic model; (c) FV, calculated using the full cubic model, for compositions of the M1 sample with LW and HW CMC additives.

[Figura 1: Projeção da superfície de resposta 3D de: (a) VA, calculada a partir do modelo linear; (b) VP, calculada a partir do modelo cúbico completo; (c) VF, calculada a partir do modelo cúbico completo, de composições da amostra M1, aditivadas com CMC LW e HW.] 


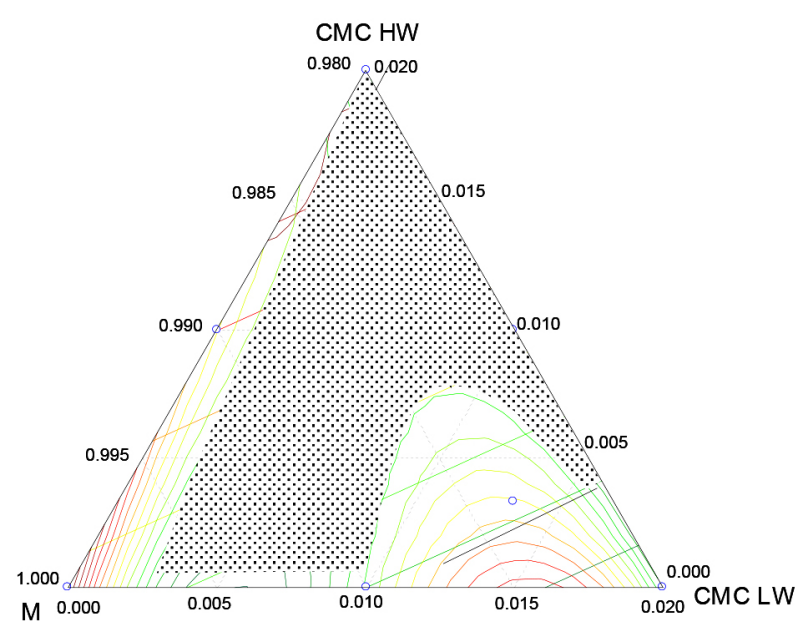

Figure 2: Superposition of the contours of parameters AV, PV and FV of compositions of the M1 sample with LW and HW CMC additives.

[Figura 2: Sobreposição das curvas de níveis dos parâmetros VA, $V P$ e VF de composições da amostra M1, aditivadas com CMC LW e HW.]

the full cubic. For this reason, it was the model chosen for the correlation equations, the $3 \mathrm{D}$ response surfaces, the contours, the response trace plots, and the statistical parameters. The values of $\mathrm{R}^{2}$ in Table IX for the most suitable model, relative to the parameters AV, PV and FV, were $0.947,0.783$ and 0.872 , respectively. Therefore, it can be stated that the models were well-adjusted for the AV and FV parameters, and somewhat adjusted for PV. The p-values in the same table indicated that the models were statistically significant at the stipulated level ( $\mathrm{p}$-value $\geq$ significance level), for the rheological parameters AV and $\mathrm{PV}$, and the filtration parameter FV. The values of $\mathrm{F}_{\mathrm{cal}}$ and the ratio between the computed and the tabulated $F$ values indicate that the models were significant for all parameters and predictive for AV. By means of the p-value in Table X, it was observed that, for parameters PV and FV, the model was not statistically significant for no adjustment at the stipulated level ( $\mathrm{p}$-value $\geq$ significance level). However, for $\mathrm{AV}$, it was significant both for the model and for no adjustment.

Based on the results achieved with replicas, regression equations correlating the mass proportions of the blends and $\mathrm{LW}$ and $\mathrm{HW}$ CMC additives with the parameters AV, PV and FV could be generated. These mathematical models are presented in Table XI. The terms of the AV equation show that the blend sample $\mathrm{M}^{*}, \mathrm{CMC} \mathrm{LW}^{*}$ and $\mathrm{HW} \mathrm{CMC}^{*}$, as well as the combinations $\mathrm{MLW}^{*}$, MLWHW* and MLW(M-LW)* were statistically significant. However, $\mathrm{M}^{*}, \mathrm{LW}^{*}, \mathrm{HW}^{*}, \mathrm{MLWHW}^{*}$ and MLW(M-LW)* interact synergistically and MLW* interacts antagonistically. Similar to what occurred with the $100 \%$ M1 sample, the coefficients of the AV equation of the $100 \% \mathrm{M} 2$ sample indicated that the HW CMC alone was the component that most influenced the increase in apparent viscosity. It was observed that the highest viscosity (greatest coefficient, 62.17) can be achieved when the three components (the sample, LW CMC, and HW CMC) are combined. The terms of the PV equation indicate that the clay sample $\mathrm{M}^{*}$, LW $\mathrm{CMC}^{*}, \mathrm{HW} \mathrm{HW}^{*}$, as well as the compositions MLW(M-LW)* and MHW(M-HW)* are statistically significant. The components $\mathrm{M}^{*}, \mathrm{LW}^{*}$, $\mathrm{HW}^{*}$ and MLW(M-LW)* interact synergistically while the component $\mathrm{MHW}(\mathrm{M}-\mathrm{HW}) *$ interacts antagonistically. Individually, the HW CMC was the component that most contributed to the increase in plastic viscosity, which was also observed with the $100 \%$ M1 sample, while the association MLW(M-LW) also played a decisive role in increasing this parameter. Through analysis of the terms of the FV equation, it can be seen that the clay sample $\mathrm{M}^{*}$, LW $\mathrm{CMC}^{*}, \mathrm{CMC} \mathrm{HW}^{*}$, and the combination MLW(MLW)* are statistically significant. The coefficients, with their respective positive and negative signs, indicated that $\mathrm{M}^{*}, \mathrm{LW}^{*}$ and $\mathrm{HW}^{*}$ interact synergistically and MLW(MLW)* interacts antagonistically, that is, the association MLW(M-LW) contributed effectively to reduction of the filtrate.

Figs. $4 \mathrm{a}, 4 \mathrm{~b}$ and $4 \mathrm{c}$ illustrate the $3 \mathrm{D}$ response surfaces for $\mathrm{AV}, \mathrm{PV}$ and $\mathrm{FV}$, respectively, for the M2 sample with

Table VII - Predicted and experimentally measured values for the rheological and filtration parameters of M1 sample compositions with LW and HW CMC additives.

[Tabela VII - Valores preditos e medidos experimentalmente para os parâmetros reológicos e de filtração de composições da amostra M1, aditivadas com CMC LW e HW.]

Component proportions (\%)

Composition
Rheological and filtration parameters

\begin{tabular}{cccccccccc} 
& $\mathrm{M}$ & LW CMC & HW CMC & $\begin{array}{c}\text { AV } \\
(\mathrm{mPa} . \mathrm{s})\end{array}$ & $\begin{array}{c}\mathrm{PV} \\
(\mathrm{mPa} . \mathrm{s})\end{array}$ & $\begin{array}{c}\mathrm{FV} \\
(\mathrm{mL})\end{array}$ & $\begin{array}{c}\mathrm{AV} \\
(\mathrm{mPa} . \mathrm{s})\end{array}$ & $\begin{array}{c}\mathrm{PV} \\
(\mathrm{mPa} . \mathrm{s})\end{array}$ & $\begin{array}{c}\mathrm{FV} \\
(\mathrm{mL})\end{array}$ \\
\hline 1 & 0.9865 & 0.0049 & 0.0086 & 18.88 & 10.73 & 17.87 & 15.00 & 11.00 & 18.40 \\
$\mathbf{2}$ & $\mathbf{0 . 9 9 0 8}$ & $\mathbf{0 . 0 0 6 9}$ & $\mathbf{0 . 0 0 2 3}$ & $\mathbf{1 7 . 0 6}$ & $\mathbf{9 . 5 4}$ & $\mathbf{1 6 . 1 1}$ & $\mathbf{1 6 . 0 0}$ & $\mathbf{9 . 0 0}$ & $\mathbf{1 6 . 9 0}$ \\
3 & 0.9858 & 0.0021 & 0.0121 & 20.17 & 12.13 & 18.92 & 19.50 & 10.00 & 17.20 \\
4 & 0.9826 & 0.0007 & 0.0167 & 21.48 & 12.77 & 18.71 & 20.00 & 11.00 & 16.90 \\
\hline
\end{tabular}



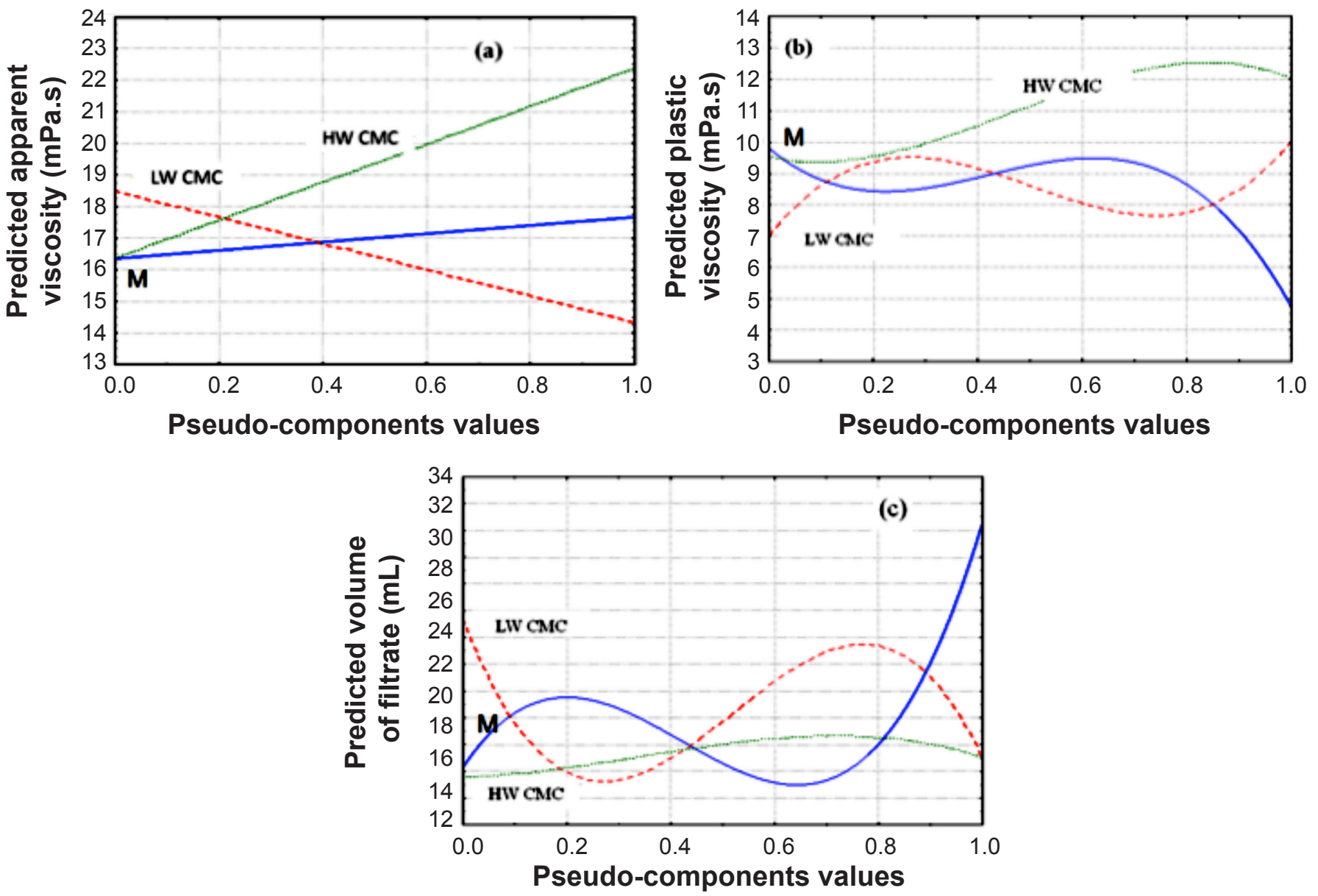

Figure 3: Response trace plot of AV (a), PV (b), and FV (c), for sample M1, proportion 0.9908, with LW CMC and HW CMC additives, proportions 0.0069 and 0.0023 , respectively.

[Figura 3: Gráfico transversal à superfície resposta de VA (a), VP (b) e VF (c) da amostra M1, proporção 0,9908, aditivada com CMC LW e CMC HW, proporções 0,0069 e 0,0023, respectivamente.]

Table VIII - Rheological and filtration parameters of compositions of the M2 sample, with LW and HW CMC additives.

[Tabela VIII - Parâmetros reológicos e de filtração de composições da amostra M2, aditivadas com CMC LW e HW.]

\begin{tabular}{ccccccc}
\hline \multirow{2}{*}{ Composition } & \multicolumn{3}{c}{ Test } & \multicolumn{4}{c}{ Repetition } \\
& AV (mPa.s) & PV (mPa.s) & FV (mL) & AV (mPa.s) & PV (mPa.s) & FV (mL) \\
\hline 1 & 17.50 & 6.00 & 34.00 & 15.00 & 5.00 & 35.00 \\
2 & 17.00 & 10.00 & 16.00 & 18.00 & 9.00 & 15.00 \\
3 & 22.00 & 10.00 & 16.00 & 23.00 & 10.00 & 16.00 \\
4 & 12.50 & 7.00 & 21.50 & 12.50 & 6.00 & 20.00 \\
5 & 21.00 & 10.00 & 20.00 & 19.50 & 9.00 & 22.00 \\
6 & 20.00 & 10.00 & 17.00 & 18.50 & 11.00 & 18.00 \\
7 & 16.00 & 7.00 & 18.00 & 16.00 & 8.00 & 19.00 \\
8 & 17.00 & 7.00 & 26.00 & 16.00 & 7.00 & 26.00 \\
9 & 17.50 & 9.00 & 18.00 & 19.00 & 10.00 & 19.00 \\
10 & 18.50 & 9.00 & 14.50 & 20.00 & 10.00 & 16.00 \\
\hline
\end{tabular}

Standard EP-1EP-00011-A (Petrobras, 2011): AV $\geq 15$ mPa.s; PV $\geq 4$ mPa.s; FV $\leq 18$ mL 
Table IX - Statistical variance analysis parameters for the variables AV, PV and FV, relative to the model, of compositions of the M2 sample, with LW and HW CMC additives.

[Tabela IX - Parâmetros estatísticos das análises de variância das variáveis VA, VP e VF, relativos ao modelo, de composições da amostra M2, aditivadas com CMC LW e HW.]

\begin{tabular}{cccccc}
\hline Variable & Model & $\mathrm{F}_{\text {cal }}$ test & $\mathrm{F}_{\text {cal }} / \mathrm{F}_{\text {tab }}$ & $\mathrm{p}$-value & $\mathrm{R}^{2}$ \\
\hline AV & Linear & 6.833 & 1.903 & 0.00664 & 0.446 \\
AV & Quadratic & 4.594 & 1.552 & 0.01089 & 0.621 \\
AV & Special cubic & 4.867 & 1.667 & 0.00814 & 0.691 \\
AV & Full cubic & $\mathbf{2 4 . 6 4 8}$ & $\mathbf{8 . 3 5 5}$ & $\mathbf{0 . 0 0 0 0 1}$ & $\mathbf{0 . 9 4 7}$ \\
PV & Linear & 7.066 & 1.968 & 0.00584 & 0.454 \\
PV & Quadratic & 2.705 & 0.914 & 0.06507 & 0.491 \\
PV & Special cubic & 2.634 & 0.902 & 0.06756 & 0.549 \\
PV & Full cubic & $\mathbf{4 . 9 5 9}$ & $\mathbf{1 . 6 8 1}$ & $\mathbf{0 . 0 0 8 4 7}$ & $\mathbf{0 . 7 8 3}$ \\
FV & Linear & 6.816 & 1.899 & 0.00670 & 0.445 \\
FV & Quadratic & 4.859 & 1.642 & 0.00873 & 0.634 \\
FV & Special cubic & 4.534 & 1.553 & 0.01076 & 0.677 \\
FV & Full cubic & $\mathbf{9 . 3 9 6}$ & $\mathbf{3 . 1 8 5}$ & $\mathbf{0 . 0 0 0 5 9}$ & $\mathbf{0 . 8 7 2}$ \\
& & & & & \\
\hline
\end{tabular}

See footnotes in Table IV.

Table X - Statistical variance analysis parameters of the variables AV, PV, and FV, of compositions of the M2 sample with LW and HW CMC additives, relative to no adjustment. [Tabela X - Parâmetros estatísticos das análises de variância das variáveis VA, VP e VF, relativos a falta de ajuste, de composições da amostra M2, aditivadas com CMC LW e HW.]

\begin{tabular}{ccccc}
\hline Variable & Model & $\mathrm{F}_{\text {cal }}$ test for no adjustment & $\mathrm{F}_{\text {cal }} / \mathrm{F}_{\text {tab }}$ & p-value \\
\hline AV & Linear & 36.747 & 11.703 & 0.00000 \\
AV & Quadratic & 43.137 & 12.396 & 0.00000 \\
AV & Special cubic & 46.168 & 12.444 & 0.00000 \\
AV & Full cubic & $\mathbf{1 5 . 4 7 1}$ & $\mathbf{3 . 1 1 9}$ & $\mathbf{0 . 0 0 2 8 1}$ \\
PV & Linear & 2.165 & 0.844 & 0.12947 \\
PV & Quadratic & 3.358 & 0.965 & 0.05474 \\
PV & Special cubic & 3.596 & 0.969 & 0.05388 \\
PV & Full cubic & $\mathbf{0 . 0 0 0}$ & $\mathbf{0 . 0 0 0}$ & $\mathbf{0 . 9 9 2 2 5}$ \\
FV & Linear & 4.784 & 1.524 & 0.01333 \\
FV & Quadratic & 4.662 & 1.340 & 0.02206 \\
FV & Special cubic & 5.113 & 1.378 & 0.02122 \\
FV & Full cubic & $\mathbf{0 . 0 0 3}$ & $\mathbf{0 . 0 0 1}$ & $\mathbf{0 . 9 6 0 0 0}$ \\
\hline
\end{tabular}

See footnotes in Table IV.

CMC LW and HW additives. The results indicate that the additive HW CMC was the component that most contributed to increasing AV and PV and reducing FV. Small amounts of LW also led to a rise in $\mathrm{AV}$ and $\mathrm{PV}$ and a reduction in FV. Fig. 5 illustrates the superposition of the contours for parameters $\mathrm{AV}, \mathrm{PV}$ and $\mathrm{FV}$ for the $100 \% \mathrm{M} 2$ sample with $\mathrm{CMC}$ additives. In the hatched area, the rheological parameters $\mathrm{AV}, \mathrm{PV}$ and $\mathrm{FV}$ meet the requirements established by Petrobras [24] for use in water-based drilling fluids. In order to validate the model, values were assigned to each of the composition components within the area where the rheological and filtration parameters met the minimum requirements of Petrobras' standard [24]. Using the corresponding mathematical equations, the predicted values for each of these parameters was computed and then the methodology described before was applied to experimentally determine the values of these parameters, which are represented in Table XII. Analyzing 
Table XI - Correlation equations of compositions of the M2 blend with LW and HW CMC additives. [Tabela XI - Equações matemáticas de correlação de composições da amostra M2 aditivadas com CMC LW e HW.]

\begin{tabular}{cl}
\hline Parameter & Equation \\
\hline $\mathrm{AV}$ & $\mathrm{AV}=13.41 \mathrm{M}^{*}+13.91 \mathrm{LW}^{*}+16.66 \mathrm{HW}^{*}-16.38 \mathrm{MLW} *+62.17 \mathrm{MLWHW}^{*}+49.38 \mathrm{MLW}(\mathrm{M}-\mathrm{LW})^{*}$ \\
$\mathrm{PV}$ & $\mathrm{PV}=7.00 \mathrm{M}^{*}+7.00 \mathrm{LW}^{*}+9.00 \mathrm{HW}^{*}+30.72 \mathrm{MLW}(\mathrm{M}-\mathrm{LW})^{*}-24.27 \mathrm{MHW}(\mathrm{M}-\mathrm{HW})^{*}$ \\
$\mathrm{FV}$ & $\mathrm{FV}=31.49 \mathrm{M}^{*}+17.49 \mathrm{LW}^{*}+17.49 \mathrm{HW}^{*}-93.42 \mathrm{MLW}(\mathrm{M}-\mathrm{LW})^{*}$ \\
\hline
\end{tabular}

Notes: $M$ - 100\% clay sample M2; LW, HW - respectively low and high molecular weight CMC; the terms indicated statistical significance at the $95.0 \%$ confidence level.
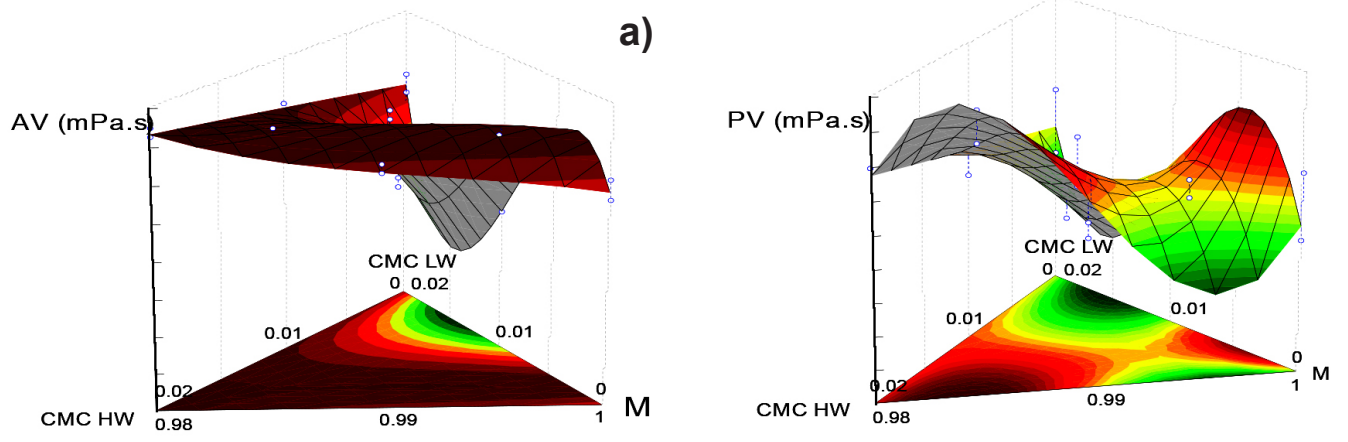

b)

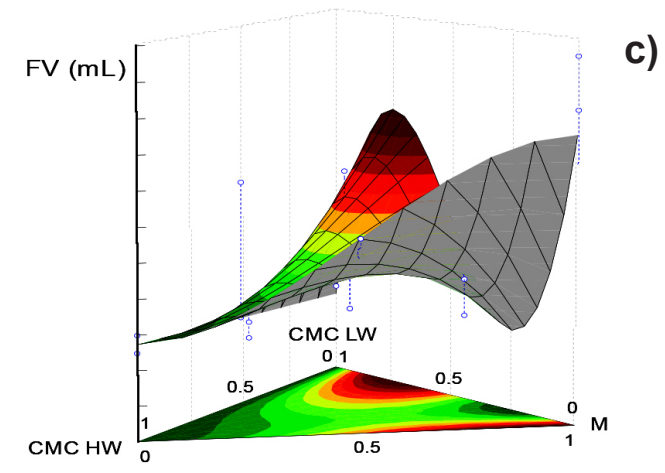

c)

Figure 4: Projection of the 3D response surface calculated using the full cubic model of AV (a), PV (b), and FV (c) for compositions of the M2 sample from Olivedos with LW and HW CMC additives.

[Figura 4: Projeção da superfície de resposta 3D calculada a partir do modelo cúbico completo de VA (a), VP (b) e VF (c) de composições da amostra 100\% M2 de Olivedos, aditivadas com CMC LW e HW.]

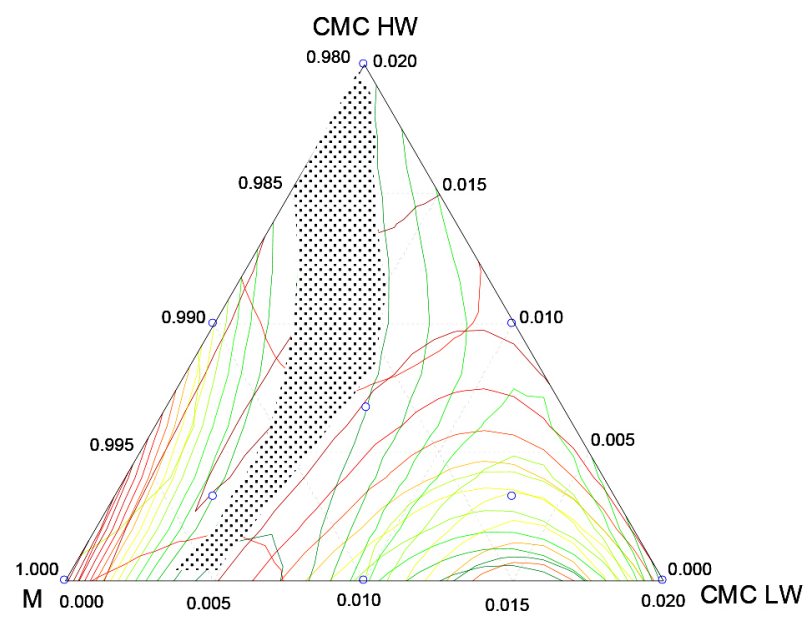

Figure 5: Superposition of the contours for the parameters AV, PV and FV of compositions of the M2 sample with LW and HW CMC additives.

[Figura 5: Sobreposição das curvas de niveis dos parâmetros VA, VP e VF de composições da amostra M2 aditivadas com CMC LW e HW.] these values, it can be concluded that the values of AV, PV and FV calculated by the mathematical equations and the values experimentally measured were similar, meaning that the statistical model was experimentally validated. In Fig. 6, the graphs are traced based on a transverse cut along the response surface or response trace plots, which is an alternative manner of visualizing the effects of the changes in proportion of the compositions on the rheological and filtration properties. The composition used to plot these graphs was composition 1, extracted from the hatched area of Fig. 5, since the predicted and experimentally measured values were the closest in this area. From Fig. 6, it can be concluded that increasing HW $\mathrm{CMC}$ leads to an increase in $\mathrm{AV}$ and $\mathrm{PV}$ and a decrease in $\mathrm{FV}$. Increasing LW CMC reduces the plastic viscosity and increases the filtrate volume. With respect to the apparent viscosity, increasing the amount of this additive has a positive effect on this parameter only in the ranges from 0 to $0.6 \%$ and 1.6 to $2 \%$. 
Table XII - Predicted and experimentally measured values for the parameters AV, PV and FV of compositions of the M2 sample with LW and HW CMC additives.

[Tabela XII - Valores preditos e medidos experimentalmente para os parâmetros VA, VP e VF de composições da amostra $M 2$, aditivadas com $C M C L W$ e $H W$.]

\begin{tabular}{|c|c|c|c|c|c|c|c|c|c|}
\hline \multirow{3}{*}{ Composition } & \multirow{2}{*}{\multicolumn{3}{|c|}{ Component proportion (\%) }} & \multicolumn{6}{|c|}{ Rheological and filtration parameters } \\
\hline & & & & \multicolumn{3}{|c|}{ Predicted values } & \multicolumn{3}{|c|}{ Test results } \\
\hline & M & LW CMC & HW CMC & $\begin{array}{c}\mathrm{AV} \\
(\mathrm{mPa} . \mathrm{s})\end{array}$ & $\begin{array}{c}\mathrm{PV} \\
(\mathrm{mPa} . \mathrm{s})\end{array}$ & $\begin{array}{c}\mathrm{FV} \\
(\mathrm{mL})\end{array}$ & $\begin{array}{c}\mathrm{AV} \\
(\mathrm{mPa} . \mathrm{s})\end{array}$ & $\begin{array}{c}\mathrm{PV} \\
(\mathrm{mPa} . \mathrm{s})\end{array}$ & $\begin{array}{c}\mathrm{FV} \\
(\mathrm{mL}) \\
\end{array}$ \\
\hline 1 & 0.9832 & 0.0019 & 0.0149 & 16.01 & 9.85 & 17.36 & 16.50 & 9.00 & 16.30 \\
\hline 2 & 0.9869 & 0.0048 & 0.0083 & 15.81 & 8.29 & 17.42 & 16.00 & 9.00 & 17.00 \\
\hline 3 & 0.9930 & 0.0048 & 0.0022 & 15.52 & 7.79 & 17.32 & 15.50 & 7.00 & 17.80 \\
\hline
\end{tabular}
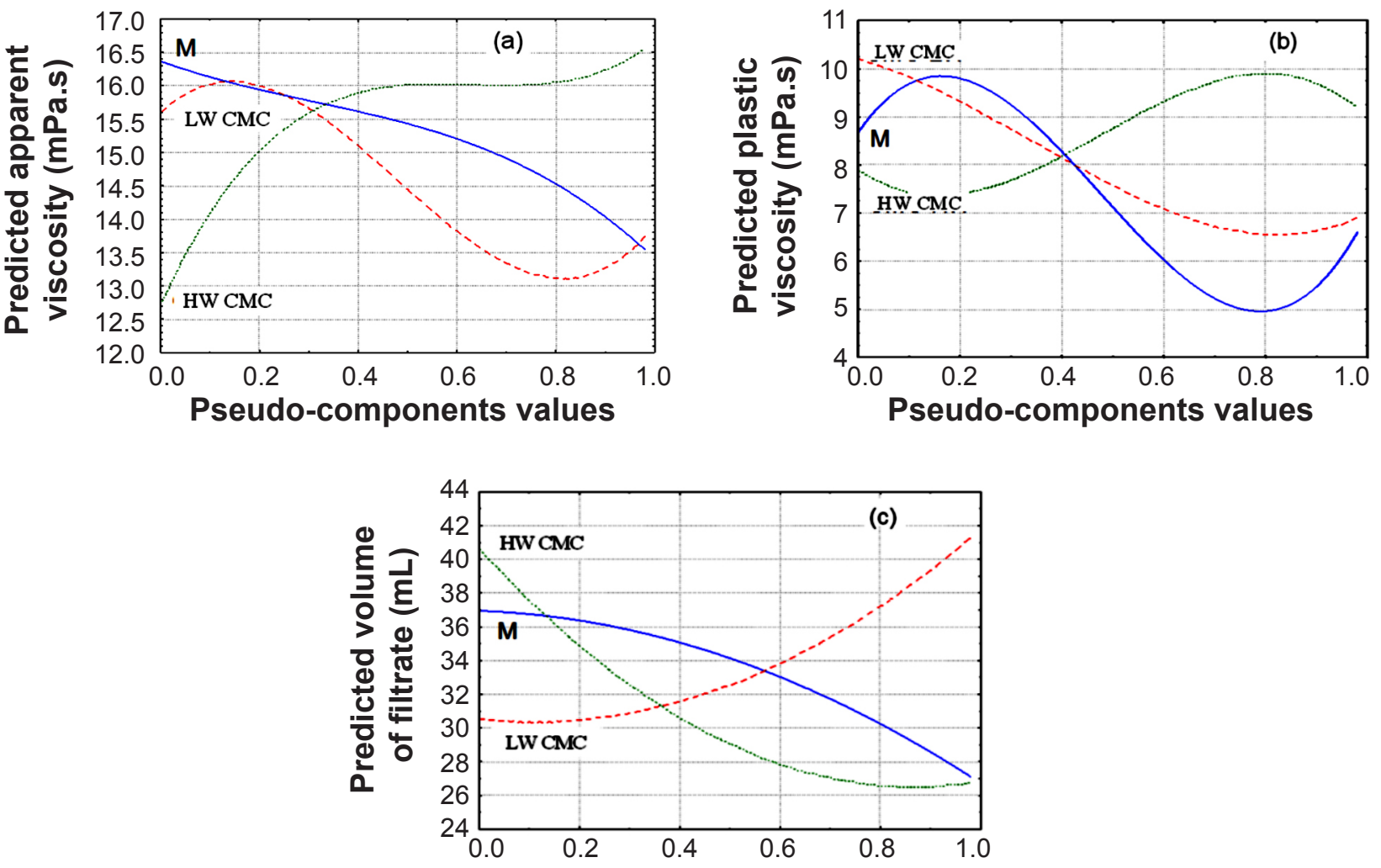

Figure 6: Response trace plot of AV (a), PV (b), and FV (c), for the M2 sample, proportion 0.9832, with LW CMC and HW CMC additives, proportions 0.0019 and 0.0149 , respectively.

[Figura 6: Gráfico transversal à superfície resposta de VA (a), VP (b) e VF (c) da amostra M2, proporção 0,9832, aditivada com CMC LW e CMC HW, proporções 0,0019 e 0,0149, respectivamente.]

\section{CONCLUSIONS}

With the objective of using experimental planning and statistical analysis techniques in order to verify the effect of LW and HW CMC on the rheological and filtration properties of bentonite clay samples from the town of Olivedos, Paraíba, Brazil, as a viscosifier for use in water-based drilling fluids, the following conclusion was reached: the blending of bentonite clay samples with LW and HW CMC enabled the production of compositions with rheological and filtration properties suitable for use in drilling fluids. Statistical data, such as the p-value of the samples with LW and HW CMC additives, indicated that the models adopted were significant for the stipulated confidence level. Similar results were found when the values of $\mathrm{F}_{\text {cal }}$ and the $\mathrm{F}_{\mathrm{cal}} / \mathrm{F}_{\text {tab }}$ ratio were evaluated. The values of the correlation coefficient $\mathrm{R}^{2}$ demonstrated that the models were well adjusted. The 3D response surfaces of the compositions with $\mathrm{CMC}$ additives indicated that the high molecular weight $\mathrm{CMC}$ most contributed to increasing $\mathrm{AV}$ and $\mathrm{PV}$, whereas the low molecular weight CMC mostly contributed 
to reducing the filtrate volume. By the predicted and experimentally determined values, it can be concluded that the established models were validated. The results showed that the experimental planning technique, through mixture delineation, proved to be an important and fundamental tool in the study of optimization and modeling of bentonite clay compositions for use in water-based drilling fluids.

\section{REFERENCES}

[1] R. Caenn, G.V. Chillingar, J. Petrol. Sci. Eng. 14 (1996) 221.

[2] R.R. Menezes, L.R.L. Melo, F.A.S. Fonseca, H.S. Ferreira, M.A.B.G. Neves, Rev. Eletr. Mater. Proc. 3 (2008) 36.

[3] E. Teixeira-Neto, A.A. Teixeira-Neto, Quím. Nova 32 (2009) 809.

[4] H.H. Murray, Appl. Clay Sci. 17 (2000) 207.

[5] R.E. Grim, N. Guven, Bentonites: geology, mineralogy, properties and uses, Elsevier (2011).

[6] H.H. Murray, Clay Miner. 34 (1999) 39.

[7] Z. Gong, L. Liao, G. Ly, X. Wang, Appl. Clay Sci. 119 (2016) 294.

[8] J. Nones, H.G. Riella, A.G. Trentin, J. Nones, Appl. Clay Sci. 105 (2015) 225.

[9] M. Mihaljevič, V. Ettler, D. Hradil, O. Šebek, L. Strnad, Appl. Clay Sci. 31 (2006) 36.

[10] H.C. Darley, G.R. Gray, Composition and properties of drilling and completion fluids, Gulf Prof. Publ. (1988).

[11] P.F. Luckham, S. Rossi, Adv. Colloid Int. Sci. 82 (1999) 43.

[12] K. Faisandier, C. Pons, D. Tchoubar, F. Thomas, Clays Clay Miner. 46 (1998) 636.

[13] L.V. Amorim, M.I.R. Barbosa, H.D.L. Lira, H.C. Ferreira, Mater. Res. 10 (2007) 53.
[14] L. Amorim, M. Barbosa, H. Ferreira, Rev. Matér. 3 (2008) 209.

[15] P.M. Bastos, B.M.A. Brito, A.J.A. Gama, J.M. Cartaxo, G.A. Neves, L.F.A. Campos, Cerâmica 63, 366 (2017) 187.

[16] S. Correia, D. Hotza, A. Segadães, Ceram. Int. 30 (2004) 917.

[17] R. Menezes, L. Marques, L. Campos, H. Ferreira, L. Santana, G. Neves, Appl. Clay Sci. 49 (2010) 13.

[18] S. Özgen, A. Yıldız, A. Çalışkan, E. Sabah, Appl. Clay Sci. 46 (2009) 305.

[19] L.F.A. Campos, L.V. Amorim, H.C. Ferreira, Cerâmica 53, 325 (2007) 68.

[20] S. Correia, K. Curto, D. Hotza, A. Segadães, J. Eur. Ceram. Soc. 24 (2004) 2813.

[21] E.N.M. Medeiros, R.M. Sposto, G.A. Neves, R.R. Menezes, Cerâmica 56, 340 (2010) 399.

[22] B. Silva, R. R. Menezes, L.N.L. Santana, L. Melo, G.A. Neves, H.C. Ferreira, Rev. Matér. 17 (2012) 919.

[23] T. Yamaguchi, Y. Sakamoto, M. Akai, M. Takazawa, Y. Iida, T. Tanaka, S. Nakayama, Phys. Chem. Earth Parts A/B/C 32 (2007) 298.

[24] Petrobras, "Ensaio de viscosificante para fluidos base água na exploração e produção de petróleo", EP-1EP00011-A (2011).

[25] H.C. Ferreira, T. Chen, A.R. Zandonadi, P. Souza Santos, Cerâmica 18 (1972) 333.

[26] M.I. Rodrigues, A.F. Iemma, Planejamento de experimentos e otimização de processos: uma estratégia sequencial de planejamentos, Casa Pão Edit. (2014).

[27] M.I.R. Barbosa, L.V. Amorim, H.C. Ferreira, Cerâmica 53, 328 (2007) 354.

[28] M.I.R. Barbosa, L.V. Amorim, H.C. Ferreira, Matéria 12 (2007) 367.

[29] K.C. Nóbrega, L.V. Amorim, Cerâmica 61, 360 (2015) 399.

(Rec. 27/07/2017, Rev. 10/10/2017, Ac. 12/11/2017) 